\title{
Survival analysis of tethered juvenile sea scallops Placopecten magellanicus in field experiments: effects of predators, scallop size and density, site and season
}

\author{
M. A. Barbeau ${ }^{1}$, R. E. Scheibling ${ }^{1}$, B. G. Hatcher ${ }^{2}$, L. H. Taylor ${ }^{1}$, A. W. Hennigar ${ }^{1}$ \\ ${ }^{1}$ Department of Biology and ${ }^{2}$ Department of Oceanography, Dalhousie University, Halifax, Nova Scotia, Canada B3H 4J1
}

\begin{abstract}
The impact of predation on survival of juvenile sea scallops Placopecten magellanicus has important implications for the population dynamics and aquaculture of this species. In field experiments using tethered juvenile scallops, we examined the effect of biological and physical factors, such as prey size, predator and prey density, water temperature (season) and site, on mortality rates of scallops in Lunenburg Bay, Nova Scotia, Canada. The major predators of juvenile scallops were crabs Cancer irroratus and sea stars Asterias spp. In an experiment manipulating scallop density, crab predation rate increased significantly with scallop density, but crab density did not, suggesting a functional response. Sea star predation rate on scallops was not affected by scallop density. In a series of experiments with different size classes of scallops tethered at different sites and seasons, and in different densities of surrounding scallops and predators, the effects of covariates on scallop survival times were assessed using the statistical procedure of survival analysis. Since the tethering technique affected crab and sea star predation differently, the competing causes of scallop mortality were analysed separately. Water temperature, site, and scallop density were the important variables affecting crab predation. There was a significant interaction between temperature and site, such that crab predation on scallops increased with temperature at one site and was independent of temperature at the other site. Predation by crabs also increased with scallop density and, to a lesser extent, with crab density. Water temperature and scallop size were the primary variables affecting sea star predation. Sea star predation on scallops increased with temperature and decreased with scallop size. The results of this study suggest options for minimizing predation of scallops by crabs and sea stars in bottom culture operations.
\end{abstract}

KEY WORDS: Placopecten magellanicus Cancer irroratus - Asterias spp. Survival analysis - Predation Prey density Prey size $\cdot$ Site $\cdot$ Temperature Tethering

\section{INTRODUCTION}

The juvenile stage of marine bivalves is generally considered to be the most vulnerable phase of their benthic life (Jensen \& Jensen 1985, Boghen 1989, Juanes 1992). Increasing interest in fisheries assessment, population enhancement and aquaculture of bivalves has focused attention on predation as an important control of juvenile survival (Peterson 1982, Jubb et al. 1983, Lake et al. 1987, Sanchez-Salazar et al. 1987, Eggleston 1990, Sponaugle \& Lawton 1990. Pohle et al. 1991) and of population size (Peterson 1990, Minchin 1991, Hatcher et al. in press). In eastern Canada, predation on juvenile sea scallops Placopecten magellanicus limits the success of bottom culture, and crabs Cancer irroratus and sea stars Asterias spp. have been shown to be the major predators (Naidu \& Cahill 1986. Tremblay 1988, Wildish et al. 1988, Picard 1992, Hatcher et al. in press). However, the rate-determining processes affecting predation of scallops by crabs and sea stars in the field have not been elucidated.

Predation rate is influenced by various biological and physical factors. For instance, laboratory experiments demonstrate that prey size and water tempera- 
ture affect predation rates by crabs and sea stars feeding on scallops (EIner \& Jamieson 1979, Lake et al. 1987, Barbeau \& Scheibling 1994a, c). Other laboratory and field experiments show that the rate of crab predation on several species of bivalves increases with prey density (Lipcius \& Hines 1986, Eggleston 1990. Sponaugle \& Lawton 1990, Eggleston et al, 1992). Density-dependent predation may result from accelerated consumption rates of individual predators (a functional response) and/or enhanced local density of predators (a numerical aggregative response) (Hughes 1980, Taylor 1984). Field studies also demonstrate that site (which encompasses many biological and physical variables) accounts for much of the variation observed in bivalve survival (Flagg \& Malouf 1983, Boghen 1989). However, the relative significance of predation in determining the site effect has rarely been assessed.

In this paper, we present an analysis of the survival of tethered juvenile sea scallops at 3 field sites. We examine the interacting effects on predation rate of various biological and physical factors (e.g. prey size and density, predator density, water temperature and site). Our experiments include 1 designed to examine the effect of scallop density on scallop mortality rate at 1 site, and a series of 5 other experiments designed to monitor the survival of different size classes of scallops tethered at different sites and seasons, and in different densities of surrounding scallops and predators. Since individual tethered scallops in the latter series of experiments were followed until mortality, the effects on survivorship of explanatory variables measured during the individuals' lifetime (i.e. covariates such as size, density, temperature, and site) were examined through survival analysis. Survival analysis (also termed hazard analysis) is a powerful statistical procedure designed for timeto-transition data (e.g. time to failure, time to conception, and other waiting times). It is frequently employed in engineering and clinical studies, but has seldom been exploited in ecological studies (Kalbfleisch \& Prentice 1980, Lawless 1982, Muenchow 1986). Through survival analysis, we are able to evaluate the effects of covariates on the distribution of survival times of individual scallops rather than simply measuring the proportion of scallops surviving at a given time. Survival analysis is particularly attractive because in addition to indicating the significance of covariates, it allows one to calculate probabilities of survival as a function of the covariates

\section{MATERIALS AND METHODS}

Description of sites. Field experiments using tethered juvenile sea scallops Placopecten magellanicus were conducted at 3 sites in Lunenburg Bay, Nova Scotia, Canada (Fig. 1). Site 1 (Corkum Island Channel, $44^{\circ} 20.5^{\prime} \mathrm{N}, 64^{\circ} 18.9^{\prime} \mathrm{W}$ ) is located in a tidal channel (1 km long, $0.35 \mathrm{~km}$ wide), on a mixed substrate (small cobbles, shell fragments and silt) at a depth of $7.5 \mathrm{~m}$ at mean low tide. The semi-diurnal tides have an amplitude ranging from 0.7 to $2.1 \mathrm{~m}$ for neap and spring tides, respectively, and tidal currents, measured $0.6 \mathrm{~m}$ above the seabed, reach up to $0.60 \mathrm{~m}$ $\mathrm{s}^{-1}$ along-channel (Hatcher et al. in press). Site 2 $\left(44^{\circ} 20.7^{\prime} \mathrm{N}, 64^{\circ} 18.8^{\prime} \mathrm{W}\right)$ is located in the open bay at the mouth of Corkum Island Channel and is more exposed. Site 2 has a substrate similar to Site 1 and a depth of $8.4 \mathrm{~m}$ at mean low tide. The tidal and current regimes at Site 2 are similar to those at Site 1, but the current velocities at Site 2 are lower and more variable. Site 3 (East Point Gut, 44 $21.1^{\prime} \mathrm{N}, 64^{\circ} 12.8^{\prime} \mathrm{W}$ ) is located in a narrow channel ( $1 \mathrm{~km}$ long, $25 \mathrm{~m}$ wide). The substrate at Site 3 is similar to that at Sites 1 and 2, but with a higher silt fraction and at a depth of $4.8 \mathrm{~m}$ at mean low tide. The tidal amplitude at Site 3 ranges from 0.7 to $1.9 \mathrm{~m}$ for neap and spring tides, respectively, and the current reaches $0.48 \mathrm{~m} \mathrm{~s}^{-1}$ alongchannel (Barbeau et al. unpubl.). All sites have naturally occurring populations of scallops.

Single-factor experiment: effect of scallop density. To examine the effect of scallop density on predation rate, an experiment using tethered scallops was conducted at Site 1 from September 27 to October 5, 1991 ( $8 \mathrm{~d}$ ). Sixteen $4 \mathrm{~m}^{2}$ plots were set up in a $4 \times 4$ matrix within a $40 \mathrm{~m}^{2}$ area, each plot separated by $10 \mathrm{~m}$. One of 4 scallop density treatments $(0,5,15$ and

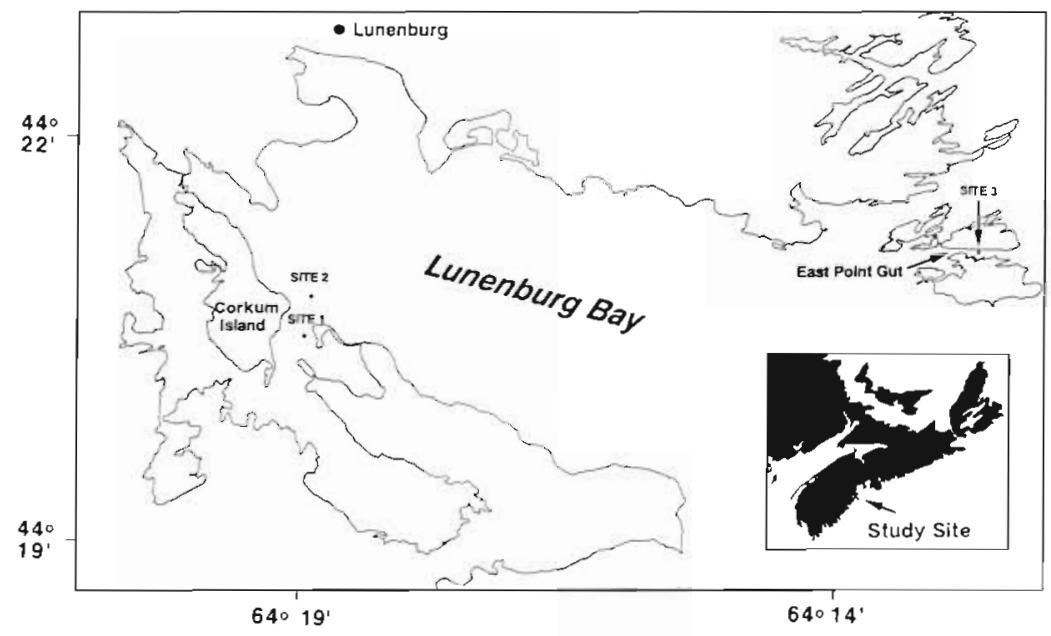

Fig. 1. Field sites in Lunenburg Bay, Nova Scotia, Canada 
45 scallops $\mathrm{m}^{-2}$ ) was randomly allocated to each plot to give 4 replicates of each treatment in a completely randomized design. In the non-zero density plots, 20 tethered scallops (13 to $18 \mathrm{~mm}$ shell height, $\mathrm{SH}$ ) were deployed (4 equally spaced rows of 5 scallops) and, in the 15 and 45 scallop $\mathrm{m}^{-2}$ treatments, free-living scallops were added to reach the appropriate densities. All plots were monitored daily (between 12:00 and 16:00 h) by SCUBA divers to record the state (alive, dead or missing) of tethered scallops, to replace dead or missing tethered scallops with live ones, to estimate the number of free-living scallops, and to count the number of crabs and sea stars in the plots. Predators of tethered scallops could be identified by the shell remains at the end of the tether: crabs left shell fragments and sea stars left empty intact valves (termed 'cluckers'). Missing scallops (i.e. the stake and tether were intact, but the scallop or shell remains were absent) were 'unassigned' since the cause of these losses was unknown. The density of live scallops within each plot was estimated daily by quadrat sampling ( 3 quadrats of $0.25 \mathrm{~m}^{2}$ ) and free scallops were added or removed to maintain designated treatment densities. Since scallops dispersed during the $24 \mathrm{~h}$ interval between sampling times, scallop density in the 4 density treatments averaged $0.07 \pm 0.03,5.2 \pm 0.4$, $14.7 \pm 0.4$, and $36.7 \pm 1.2$ scallops $\mathrm{m}^{-2}( \pm \mathrm{SE}, \mathrm{n}=4)$, respectively, over the duration of the experiment. Predator density and scallop mortality rate in each plot were calculated as the total number of predators and dead tethered scallops, respectively, recorded during the experiment divided by the duration (in days) of the experiment.

A randomly chosen plot was monitored for $24 \mathrm{~h}$ with an underwater camerahead linked to a time-lapse ( 3 frames $10 \mathrm{~s}^{-1}$ ) video recorder (Fuhram Diversified Inc.). The infrared-sensitive camerahead was mounted on a scaffolding to give a field of view of $0.34 \mathrm{~m}^{2}$, and was surrounded by 2 banks of infrared lights which were triggered on at dusk and off at dawn. During the experiment, 2 replicate plots in each treatment group were monitored in this way. However, the video system failed on both a 0 and a 5 scallop $\mathrm{m}^{-2}$ plot, and the remaining plots from these 2 treatments were pooled for analysis. The video recordings were used to quantify the number of entrances by predators into the field of view, the movement velocities of these predators (the path of 3 randomly chosen crabs and sea stars per plot was measured and timed), and the average time and cumulative time (i.e. the sum of all time periods over the $24 \mathrm{~h}$ time interval) that predators spent within the field of view. Although predation by crabs and sea stars was observed on the video recordings, loss of tethered scallops due to other causes was too infrequent to be detected by this means.
Juvenile scallops were obtained from spat collectors in Passamaquoddy Bay, New Brunswick, Canada, through a commercial supplier (The Great Maritime Scallop Trading Co.). Prior to experiments, scallops were held in $140 \mathrm{l}$ tanks with flowing ambient seawater for $1 \mathrm{wk}$ and continually drip-fed to maintain $\sim 1 \times 10^{4}$ cells $\mathrm{ml}^{-1}$ of cultured algae (a mixture of T-Isochrysis galbana, Thalassiosira pseudonana and Chaetoceros muelleri). To tether scallops, a small area of the upper valve of a scallop was cleaned with a cotton swab and acetone (care was taken not to expose the scallop's mantle edge to acetone) and dried with an airjet (Barbeau \& Scheibling 1994b, Hatcher et al. in press). One end of a 20 to $25 \mathrm{~cm}$ monofilament line (Berkley Trilene XL, $8 \mathrm{lb}$, ca $4 \mathrm{~kg}$ ) was glued to the valve using fast-set clear epoxy or cyanoacrylate glue, and other end was tied to a stainless steel stake $(12 \mathrm{~cm}$ length, $0.5 \mathrm{~cm}$ diameter) with a numbered tag. An effective tether length of $17 \pm 1 \mathrm{~cm}$ (mean $\pm \mathrm{SD}$ ) was achieved after gluing and tying. Tethered scallops were maintained in the laboratory for 1 to $2 \mathrm{~d}$ before being transported to the field. In the field, surplus tethered and free scallops were held in pearl nets attached to a surface float. Mean ( $\pm \mathrm{SD}, \mathrm{n}=9$ ) water temperature was $12.5 \pm 2.1^{\circ} \mathrm{C}$ during the experiment.

Two congeneric species of predatory sea stars (Asterias vulgaris and $A$. forbesi) co-occur in Lunenburg Bay where the field experiments were conducted. The 2 species were combined into a functional group after verifying in a laboratory experiment that their behaviours and foraging rates on scallops (e.g. predation rate, percent searching time, encounter rate with scallops, probability of capturing scallops) did not differ significantly (Barbeau 1994)

Multifactor experiments: effects of scallop size, scallop and predator density, site and season. To examine the effect of scallop size, scallop and predator density, site and season (water temperature) on juvenile scallop survival, 5 tethering experiments (A to E) were conducted between July 1991 and June 1992 at Sites 2 and 3 (Table 1). Thirty tethered scallops, 10 from each of 3 size classes (small: $7-12 \mathrm{~mm}$, medium: 13-18 $\mathrm{mm}$, large: $23-28 \mathrm{~mm} \mathrm{SH}$ ) were randomly arranged at $-30 \mathrm{~cm}$ intervals in a circular array $1.5 \mathrm{~m}$ radius). There were 3 or 4 replicate circular arrays separated by 20 to $50 \mathrm{~m}$ at each site. Tethered scallops were monitored by SCUBA divers daily for the first $2 \mathrm{~d}$, then weekly for the first month, and monthly thereafter. On each monitoring day, the state of each tethered scallop and the type of shell remains were recorded as described above (single-factor experiment: effect of scallop density). The experiments were terminated when the proportion of dead or missing tethered scallops reached 80 to $90 \%$ of the original number. 


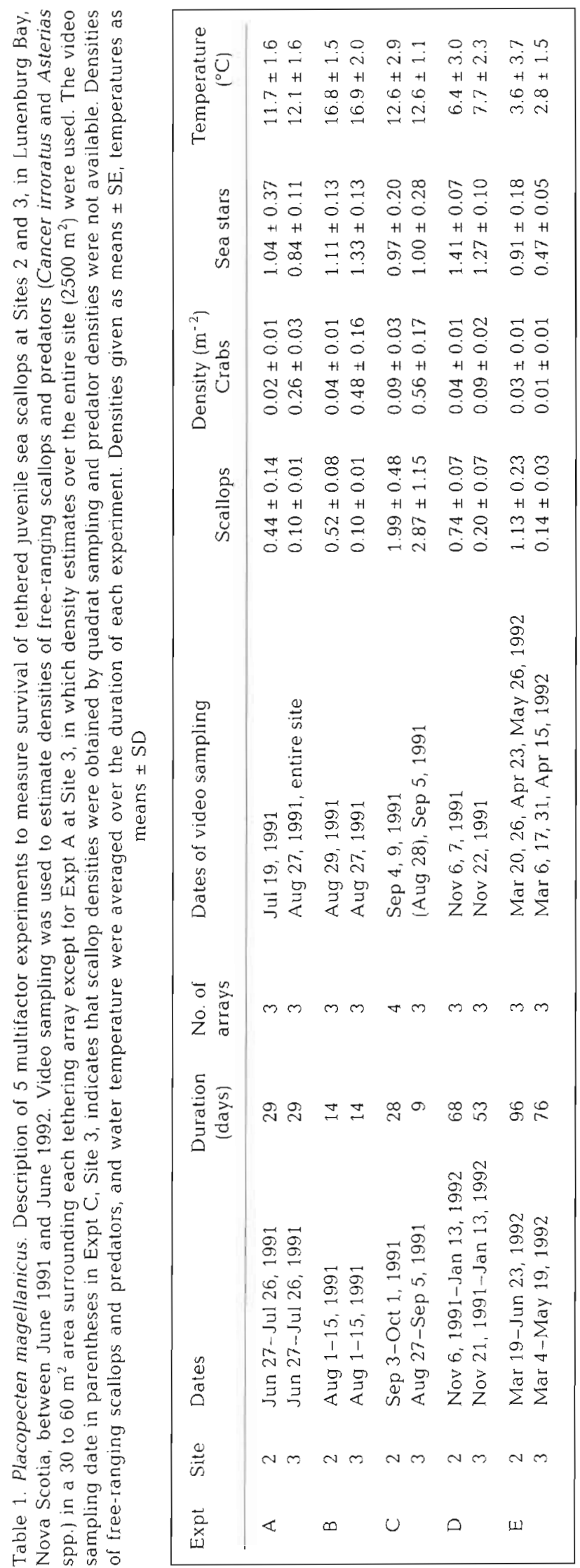

As controls for tether loss and mortality due to handling, 9 tethered scallops ( 3 from each size class) were concurrently placed in a cage ( $1 \mathrm{~m}$ diameter, $0.5 \mathrm{~m}$ high, $15 \mathrm{~mm}$ mesh aperture) anchored to the substratum at Site 1 and in a pearl net $(35 \mathrm{~cm} \times 35 \mathrm{~cm}$ bottom dimensions; $8 \mathrm{~mm}$ mesh aperture) suspended 1 to $2 \mathrm{~m}$ above bottom at Sites 2 and 3 . The proportion of tether loss for scallops in the cage was minimal (mean $\pm \mathrm{SD}$ : $0.08 \pm 0.04, n=5$ ). There was no mortality of tethered scallops in the pearl net during any experiment.

Juvenile scallops were obtained from the commercial supplier or from an experimental hatchery at Sandy Cove, Nova Scotia, (Fisheries Resource Development Limited). They were maintained in the laboratory for up to $10 \mathrm{wk}$ prior to an experiment and tethered as described above (single-factor experiment: effect of scallop density).

These tethering experiments were run concurrently with large-scale bottom seeding experiments with similar juvenile scallops (Hatcher et al. 1993, Barbeau et al. unpubl.). In these seeding experiments, 9 to 20 thousand scallops were released within a $5000 \mathrm{~m}^{2}$ area $(50 \times$ $100 \mathrm{~m})$ at Site 2 and a $2500 \mathrm{~m}^{2}$ area $(25 \times 100 \mathrm{~m})$ at Site 3 in late summer 1991 (September 3 at Site 2 and August 27 at Site 3) and late winter 1992 (March 18 at Site 2 and March 5 at Site 3). The density of free scallops, therefore, varied with the seeding schedule, dispersion and mortality of the seeded populations. During each tethering experiment, scallop and predator abundances were sampled by video camera (Sony V801 High-8 videorecorder in an Amphibico housing) in transects $(0.5 \mathrm{~m}$ wide $\times 100 \mathrm{~m}$ long) running parallel at 2.5 or $5 \mathrm{~m}$ intervals within the seeded area at 1 to 4 dates at each site (Table 1). The densities of free scallops and of their major predators, rock crabs Cancer irroratus and sea stars Asterias vulgaris and A. forbesi, were estimated from the videotapes by averaging the counts of scallops and predators in successive $1 \mathrm{~m}\left(0.5 \mathrm{~m}^{2}\right)$ sections of transects within a $30 \mathrm{~m}^{2}(3 \times 10 \mathrm{~m})$ to $60 \mathrm{~m}^{2}(6 \times 10 \mathrm{~m})$ area surrounding each circular array ( $\mathrm{n}=9$ to 30 sections). Two exceptions were: (1) Expt A at Site 3, in which video estimates of scallop and predator density over the entire site $\left(2500 \mathrm{~m}^{2}\right)$ were used, and (2) Expt $\mathrm{C}$ at Site 3 on 1 sampling date (August 28, 1991), in which estimates of scallop density were obtained from quadrat $\left(0.25 \mathrm{~m}^{2}\right)$ sampling rather than video sampling and estimates of predator density were not available (Table 1). Scallop and predator densities were averaged over all sampling days during each tethering experiment.

Seawater temperature was monitored by various means: (1) by diver's temperature gauge at each sampling time (all sites), (2) min-max thermometers reset at each sampling time (Site 2), (3) hourly logging on a in situ current meter (Emerson \& Grant in press) stationed $1 \mathrm{~km}$ southeast of Site 2, and (4) Ryan record- 
ing thermograph (Site 3). Temperature was averaged over the duration of each tethering experiment using the most accurate data available (Table 1).

Statistical analysis. The single-factor experiment at Site 1 was analyzed by 1 -way, fixed-factor analysis of variance (ANOVA). The fixed factor was scallop density, and the response variables were: (1) mortality rate of tethered scallops, (2) density of predators, (3) number of entrances of predators into the video field of view, (4) average time that predators spent within view, and (5) cumulative time that predators spent within view. The multifactor experiments ( $A$ to $E$ ) at Sites 2 and 3 were analyzed by 2- or 3-factor, repeated-measures ANOVA (Winer 1971). The repeated factor was time. The fixed factors were site and scallop size in Expts A and B, and scallop size in the remaining experiments at each site. The response variable was the proportion of tethered scallops alive. All response variables in the single-factor and multifactor experiments satisfied the assumption of homogeneity of variance based on Cochran's test. The assumption of equal covariance in the repeated-measures ANOVA was tested using the sphericity test (Crowder \& Hand 1990, Dixon 1990). If the data were non-spherical, then the degrees of freedom of the sources of variation with the repeated factor were adjusted using GreenhouseGeisser estimate $\varepsilon$. Multiple comparisons of means were performed using Student-Newman-Keul's test or Tukey's method (if the number of comparisons was $>4$ ). The error mean squares used in the post hoc tests were calculated as described in Winer (1971).

Since each tethered scallop was numbered in Expts A to $E$ at Sites 2 and 3, time to mortality of individual scallops was known. Survival times were analyzed using Cox' Proportional Hazards Model (a commonly used model in survival analysis), which allows assessment of the effects of covariates on scallop survival. Covariates used in the survival analysis included scallop size, scallop and predator density (estimated from video transects), water temperature, and site (scallop size and site were categorical variables). The proportional hazards model is given by:

$$
h(t \mid \mathbf{x})=h_{0}(t) \mathrm{e}^{\mathrm{x} \beta},
$$

where the hazard function (i.e. instantaneous mortality rate) at time $t$ for a vector of covariates $\mathbf{x}$ [i.e. $h(t \mid \mathbf{x})]$ is equal to the baseline hazard function at time $t\left[h_{0}(t)\right.$, i.e. when all covariates $=0]$ multiplied by the exponent of $\mathbf{x} \beta$, where $\mathbf{x} \beta=x_{1} \beta_{1}+\ldots+x_{p} \beta_{p}$ and $\beta_{\text {i }}$ are unknown coefficients (Kalbfleisch \& Prentice 1980, Lawless 1982). If the coefficients are all equal to zero (i.e. the covariates have no effect on survival), then the hazard function $[h(t \mid \mathbf{x})]$ is equal to the baseline hazard function $\left[h_{0}(t)\right]$. If some or all of the coefficients are different than zero, then the exponent term $\left(e^{x \beta}\right)$ is positive and the hazard function is a multiple of the baseline hazard function, hence the name proportional hazards model. The proportional hazards model uses the survival times to estimate the baseline hazard function, which is arbitrary and not necessarily biologically meaningful. Of greater interest, the model also estimates the coefficients of the covariates, which are then tested to determine whether they differ significantly from zero. The hazard function is related to the survival function (i.e. probability of survival) as the negative derivative of the natural logarithm of the survival function. Survival analysis also allows the use of partial observations (termed 'censored' observations) of individuals which were not observed for the full time to mortality, given that one knows a minimum length of time during which mortality did not occur. In our study, censored observations included scallops which went missing (e.g. due to tether loss), died of causes other than the cause of interest, or were still alive at the end of an experiment. Survival analysis was performed using BMDP (Dixon 1990). The assumption of proportional hazards between different levels of a covariate was checked graphically (Kalbfleisch \& Prentice 1980, Dixon 1990). The significance of 2 -way interactions between all covariates and of each covariate on scallop survival was tested using likelihood ratio tests (Lawless 1982, Dixon 1990). Diagnostic checks were performed and the models were deemed adequate (Kalbfleisch \& Prentice 1980, Lawless 1982).

\section{RESULTS}

\section{Single-factor experiment: effect of scallop density}

Immediately before the experiment examining the effect of scallop density on predation rate, predator densities did not differ significantly between plots $(F=$ $1.00,1.78$, and $0.67, \mathrm{df}=3,12, \mathrm{p}>0.20$, for Cancer irroratus, Asterias vulgaris, and $A$. forbesi, respectively). After initiation of the experiment, crab predation rate on tethered scallops (as indicated by shell fragments) increased with scallop density $(F=5.51, \mathrm{df}=2,9$, $\mathrm{p}<0.05$; Fig. 2a). Mean crab density also increased (Fig. 2b); however, we did not detect a statistically significant difference in crab density among scallop density treatments $(F=1.31$, df $=3,12, p>0.20)$. This may be due to the high variability in crab density between replicates and the low power of the analysis to detect this difference $(\phi=0.5$, df $=3,12$, power $=0.2$; Winer 1971). There were no significant differences in sea star predation rate on tethered scallops, as indicated by cluckers $(F=0.38, \mathrm{df}=2.9, \mathrm{p}>0.50$; Fig. $2 \mathrm{a})$, or in sea star density $(F=1.36, \mathrm{df}=3,12, \mathrm{p}>0.20$; Fig. $2 \mathrm{~b})$ among scallop density treatments. There also were no significant differences in the number of tethered 

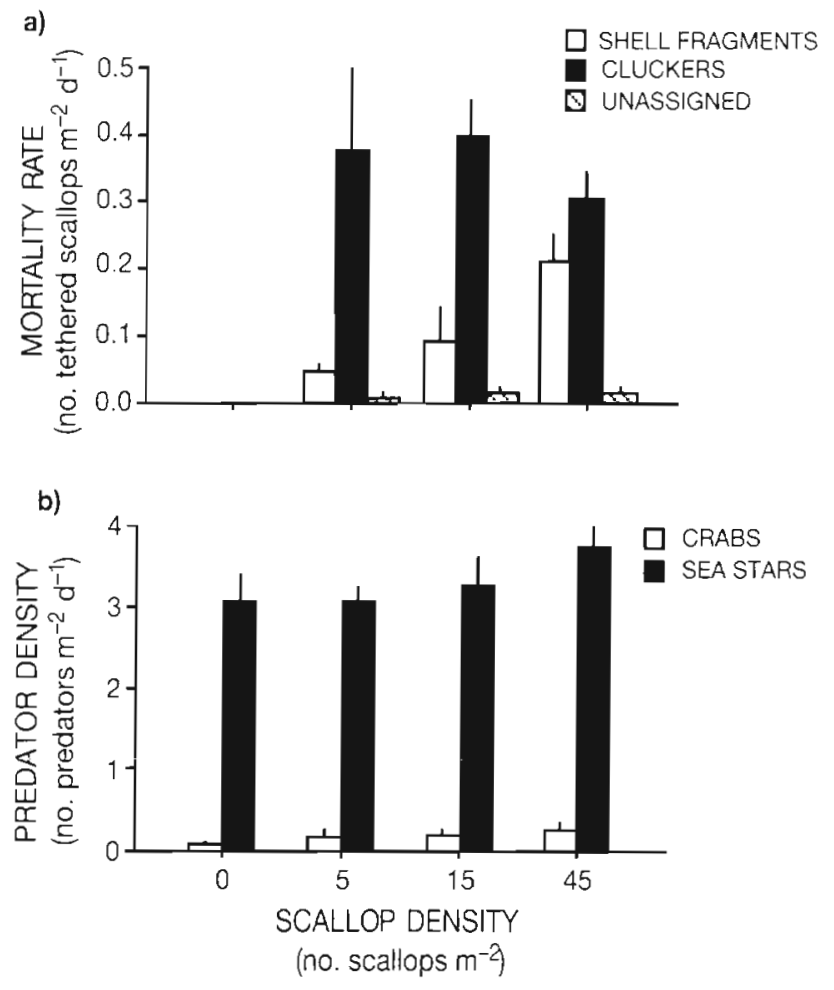

Fig. 2. Placopecten magellanicus. Results of the single-factor experiment using tethered scallops at Site 1 in Lunenburg Bay. (a) Scallop mortality rate for each type of shell remains, and (b) density of predatory crabs Cancer irroratus and sea stars Asterias spp. at different scallop densities. Mean $\pm \mathrm{SE}$ shown for all variates $(n=4)$ scallops with an unassigned mortality among scallop density treatments $(F=0.27$, df $=2,9, \mathrm{p}>0.50$; Fig. $2 \mathrm{a}$ ).

Video analysis indicated that the number of crabs Cancer irroratus or sea stars Asterias spp. entering the $0.34 \mathrm{~m}^{2}$ video field of view, and the average time and cumulative time these predators were in view, did not vary significantly with scallop density for crabs: $0.8<$ $F<2.0, \mathrm{df}=2,3, \mathrm{p}>0.20$; for sea stars: $0.07<F<0.12$, $\mathrm{df}=2,3, \mathrm{p}>0.50$ ), although the power of the analyses to detect differences was low due to the low level of replication $(\phi=1, \mathrm{df}=2,3$, power $=0.2)$. When the video observations were pooled across scallop density treatments, an average $\left( \pm \mathrm{SE}_{i} \mathrm{n}=6\right)$ of $7.7 \pm 1.4$ rock crabs and $10.9 \pm 1.7$ sea stars were observed entering the field of view over a $24 \mathrm{~h}$ interval. Crabs spent $0.06 \pm 0.02 \mathrm{~h}$ in view $(\mathrm{n}=6)$ and moved at a mean velocity of $66.6 \pm 19.1 \mathrm{~cm} \mathrm{~min}^{-1}(\mathrm{n}=18)$. Sea stars spent $2.11 \pm 0.55 \mathrm{~h}$ in view and moved at a mean velocity of $1.1 \pm 0.1 \mathrm{~cm} \mathrm{~min}^{-1}$. The cumulative time that crabs and sea stars spent in view during the $24 \mathrm{~h}$ interval was $0.5 \pm 0.2$ and $24.2 \pm 7.7$ h, respectively $(n=6)$.

\section{Multifactor experiments: effects of scallop size, scallop and predator density, site and season}

In tethering experiments in summer 1991 (Expts A and $B$ ), before Sites 2 and 3 were seeded with juvenile scallops, large tethered scallops had a higher survivorship than small and medium scallops (Table 2 ,

Table 2. Placopecten magellanicus. Repeated measures ANOVA and SNK or Tukey's test results for tethered scallops of different sizes surviving over time in the multifactor experiments at Sites 2 and 3. Expts A and B were each conducted at Sites 2 and 3 at the same time; therefore, the factor 'Site' was included in the analysis of these experiments. The remaining experiments were conducted at Sites 2 and 3 at different times, and, therefore, were analyzed separately for each site. When the data were nonspherical, the degrees of freedom of the sources of variation with the repeated factor were adjusted using Greenhouse-Geisser estimate $\varepsilon$, a measure of deviation from sphericity. T1 to 9 are consecutive monitoring times; S: small, M: medium, L: large

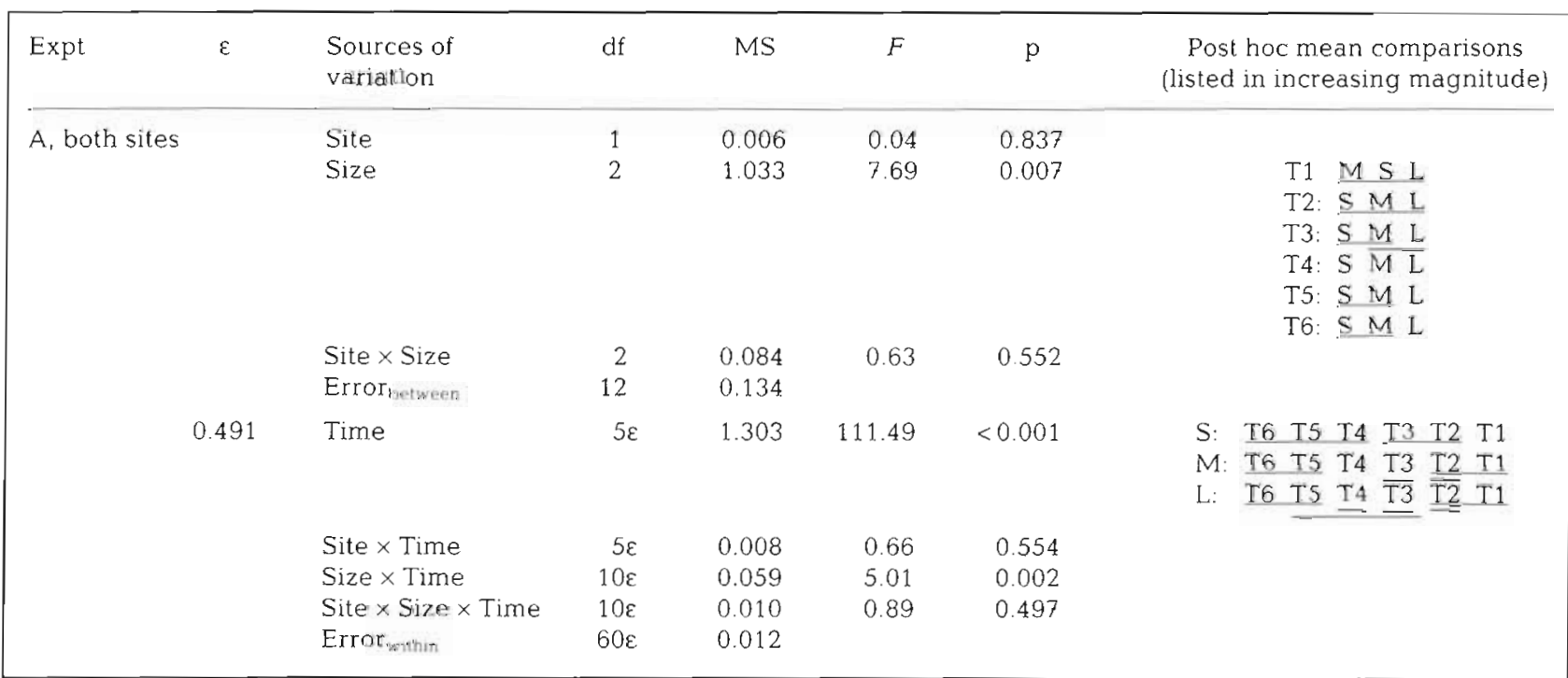


Table 2 (continued)

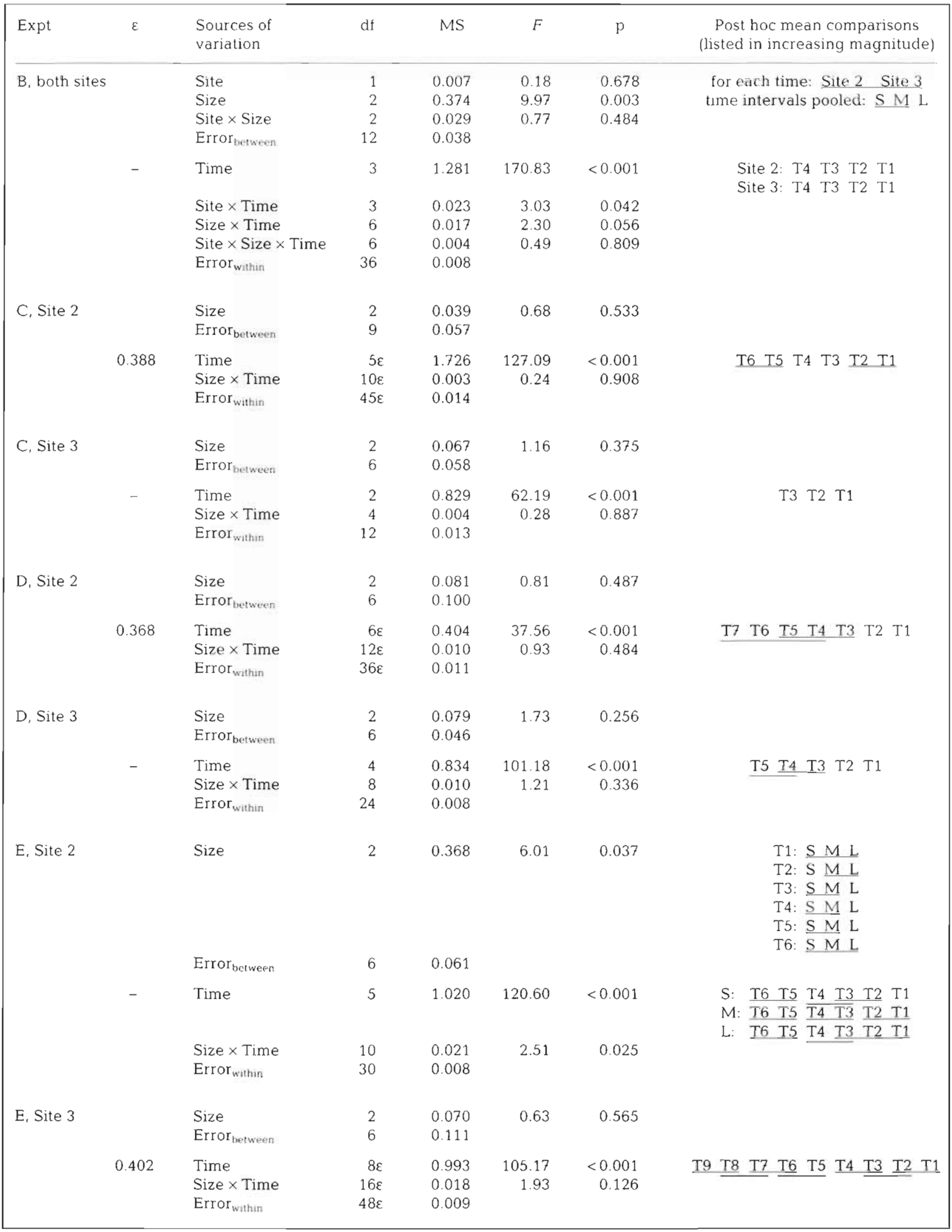



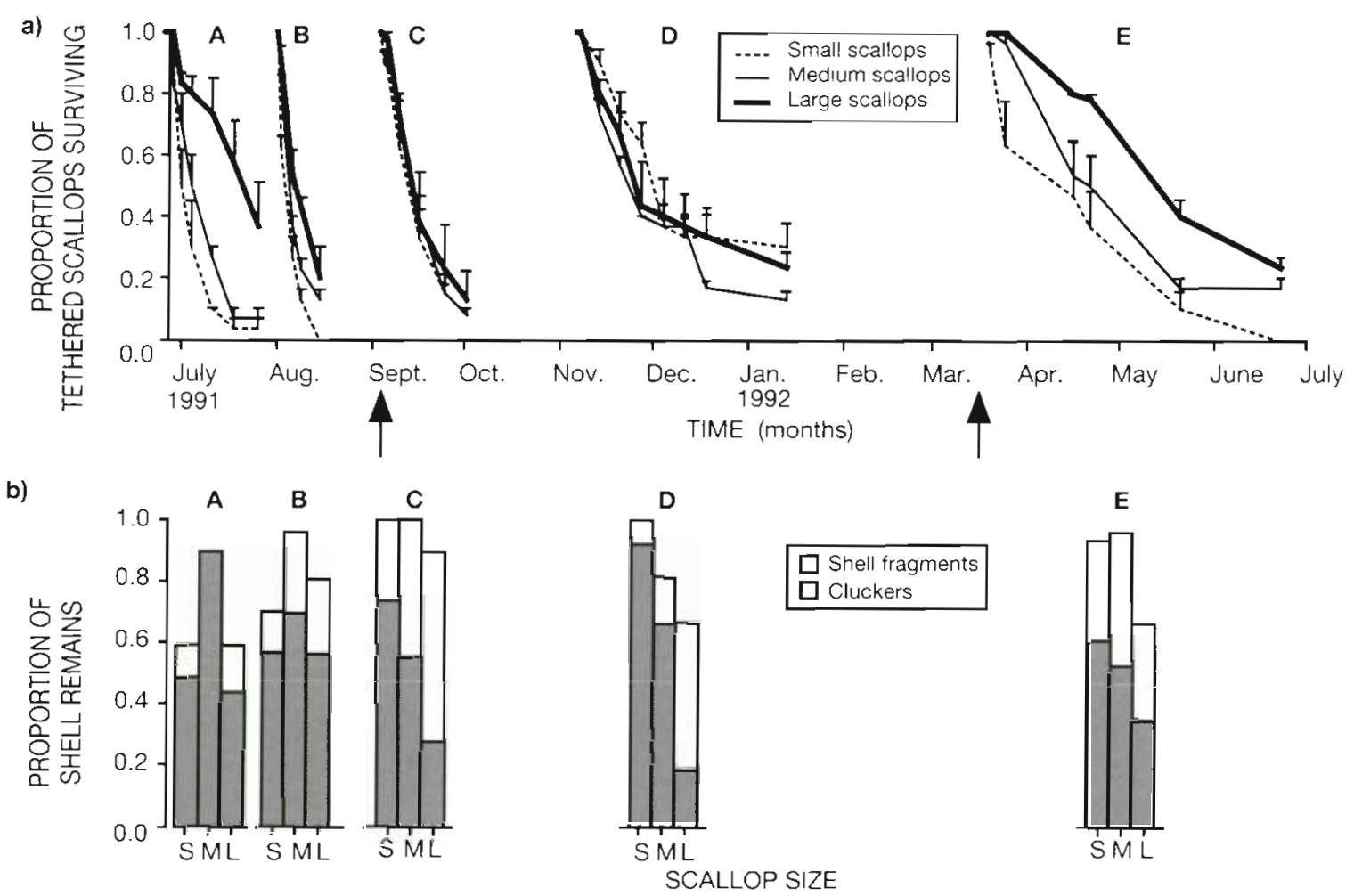

Fig 3. Placopecten magellanicus. Results of the multifactor experiments (A to E) at Site 2 in Lunemburg Bay. (a) Survival curves of tethered scallops for each scallop size class, averaged over 3 or 4 circular arrays (error bars $=$ SE). (b) Proportion of the different types of shell remains in each scallop size class (S: small, M: medium, L: large) at the end of the experiments. The remainder represents scallops with an unassigned cause of mortality. Arrows indicate dates at which the site was seeded with juvenile scallops

Figs. 3a \& 4a). Shell remains indicated that most of the predation of all size classes was by sea stars (Figs. $3 b$ \& 4 b). However, in late summer (Expt C), after increasing scallop density at Sites 2 and 3 through seeding, there were no longer any size-related differences in scallop survivorship (Table 2, Figs. 3 a \& 4a), and shell remains indicated that crabs were generally the more important predators particularly for the large size class of scallops (Figs. 3b \& 4b). In late fall and winter (Expt D), there also were no size-related differences in scallop survivorship (Table 2), but scallop survival time increased (Figs. 3a \& 4a). Crabs continued to be a major cause of mortality among the large size class of scallops (Figs. $3 \mathrm{~b} \& 4 \mathrm{~b}$ ). In the final set of experiments (Expt E), after reseeding both sites in late winter, scallop survival time remained high, and large scallops tended to have a higher survivorship than smaller scallops at Site 2 but not at Site 3 (Table 2, Figs. 3a \& 4a). Scallops at Site 3 generally experienced more crab predation than those at Site 2 (Figs. $3 b$ \& 4 b). A significant Size $\times$ Time interaction on the proportion of scallops surviving was observed in Expts $A$ and $E$ at Site 2 (Table 2), reflecting the higher survival over time of large scallops compared to small and medium scallops (Figs. 3a \& 4a).
Tables 3 \& 4 give the results of the Cox Proportional Hazards Analysis of scallop survival times in all experiments (A to E) combined, and the models (Models 1 and 2) quantify the relationship between survivorship and a set of explanatory variables (scallop size, site, density of surrounding scallops, density of predators, and water temperature, a seasonal variable; see Table 1). Crab and sea star predation were competing causes of scallop mortality. Since laboratory experiments indicated that the tethering procedure affected crab predation and sea star predation differently (Barbeau \& Scheibling 1994b), scallop survival times were analysed separately for crab-specific mortality (while censoring sea-star-specific mortality; Table 3) and seastar-specific mortality (while censoring crab-specific mortality; Table 4). This procedure assumes that the removal of 1 cause of mortality reduces the hazard function for that cause to zero and leaves the hazard for the other cause unchanged. This assumption was checked graphically and satisfied since the cause-specific hazards approximated proportionality (Lawless 1982).

For crab-specific mortality of scallops (proportion of observations censored $=0.71$, number of cases $=930$ ), Model 1 includes all covariates except non-significant 2 -way interaction terms, and Model 2 only includes the 

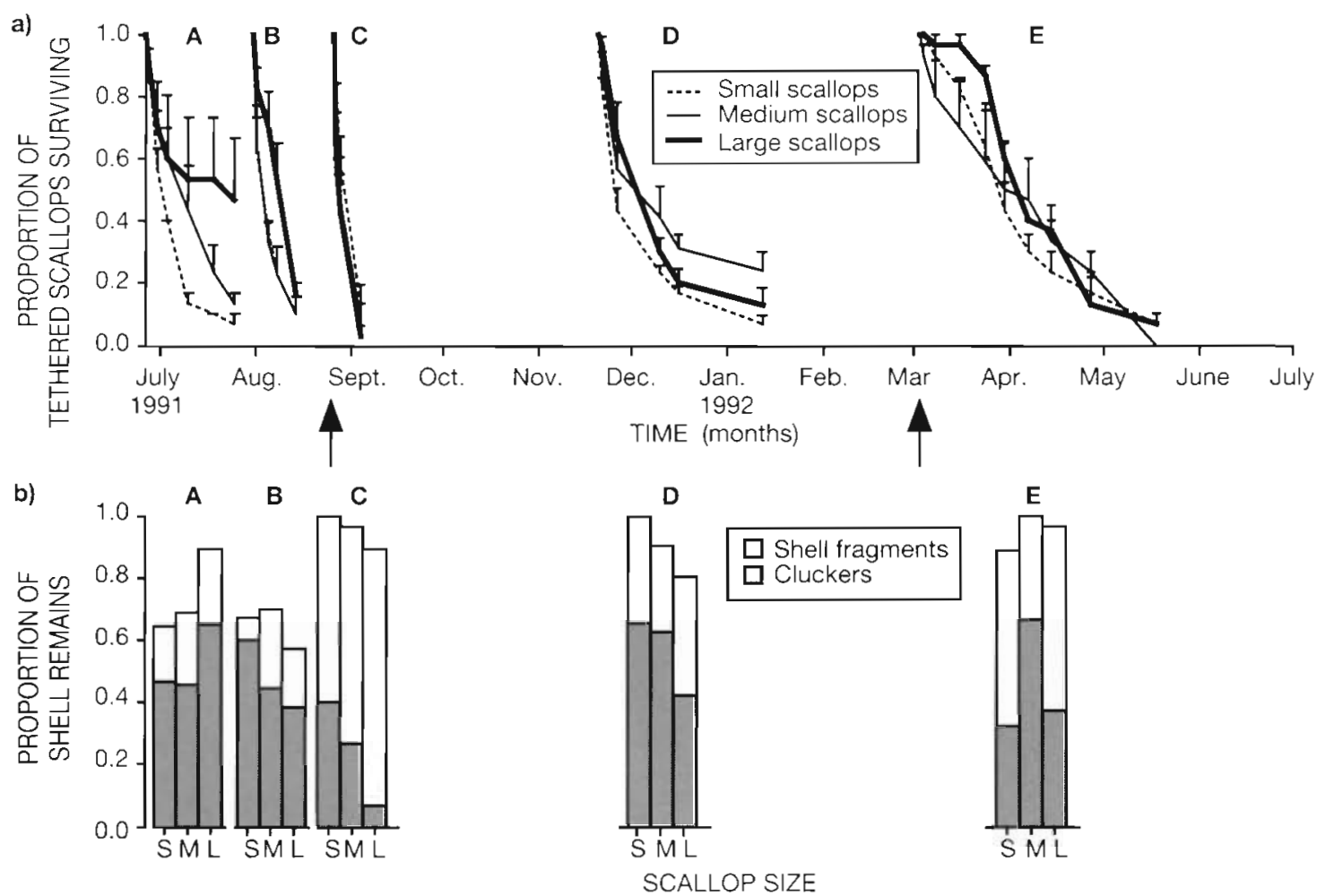

Fig. 4. Placopecten magellanicus. Results of the multifactor experiments (A to E) at Site 3 in Lunenburg Bay. (a) Survival curves of tethered scallops for each scallop size class, averaged over 3 circular arrays (error bars $=\mathrm{SE}$ ). (b) Proportion of the different types of shell remains in each scallop size class (S: small, M: meduum, L: large) at the end of the experiments. The remainder represents scallops with an unassigned cause of mortality. Arrows indicate dates at which the site was seeded with juvenile scallops

significant covariates (Table 3). The global $\chi^{2}$ of both Models 1 and 2 was significant, indicating that at least one of the included covariates significantly affected the instantaneous mortality rate. Excluding the nonsignificant covariates of Model 1 from Model 2 did not greatly change the coefficients of the covariates of Model 2. A positive coefficient of a covariate indicates that the instantaneous mortality rate increases (i.e. survival decreases) with increasing value of the covariate; a negative coefficient indicates the reverse. The hazard function $[h(t)]$ of scallops due to crab predation is calculated, using Model 2 (Table 3) for example, as $h_{0}(t) \exp (0.121$ Temperature + 1.994 Site 0.130 Temperature $\times$ Site +0.480 Scallop density + $1.077 \mathrm{Crab}$ density); and the survival function is equal to the exponent of the negative integral of the hazard function. In the analysis of scallop mortality attributed to crab predation, there was a significant interaction between site and temperature (Table 3): at Site 2, the probability of survival of scallops was highest at low temperature and decreased with increasing temperature (Fig. 5a); at Site 3, the probability of survival was similar for different temperatures (Fig. 5b). All other 2-way interactions did not significantly affect scallop mortality (likelihood ratio $\chi^{2}=16.71$ when comparing a model including all interactions to Model 1 in Table 3 , $\mathrm{df}=13, \mathrm{p}>0.05$ ). Although the instantaneous mortality rate increased with scallop size (Size1 compares medium scallops to small ones, Size2 compares large scallops to small ones, and the effect of small size on survival is incorporated in the baseline hazard), scallop size did not have a significant effect on crab predation (Table 3, Model 1). Scallop density had a highly significant effect on crab predation: the instantaneous mortality rate of scallops increased with scallop density (Table 3, Model 2; Fig. 5). Crab density had a marginally significant effect on crab predation: the instantaneous mortality rate increased with crab density (Table 3, Model 2).

For the sea-star-specific mortality of scallops (proportion of observations censored $=0.56$, number of cases $=$ 930), Model 1 includes all main (i.e. non-interaction) covariates; Model 2 includes only the temperature and scallop size covariates (Table 4 ). The global $\chi^{2}$ of both Models 1 and 2 was significant, indicating that at least 1 of the included covariates significantly affected the instantaneous mortality rate. None of the 2-way interactions was significant (likelihood ratio $\chi^{2}=19.56$ when comparing a model including all interactions to Model 1 of Table 4, df $=14, p>0.05$ ). Site, scallop density and sea 
Table 3. Placopecten magellanicus. Cox Proportional Hazards Analysis for mortality of scallops due to predation by crabs Cancer irroratus in the multfactor experiments at Sites 2 and 3 in Lunenburg Bay, Model 1 quantitıes the relationship between scallop mortality and all covariates except the nonsignificant 2 -way interaction terms. Model 2 includes only the significant covariates. The coefficient and its SE are shown for each covariate within each model. To test the significance of a covariate, the log likelihood of a submodel that excludes that particular covariate is statistically $\left(\chi^{2}\right)$ compared to the log likelihood of the full model (Model 1 or Model 2; listed on bottom line). The likelihood ratio test is defined as $-2(\log$ likelihood of submodel - $\log$ likelihood of full model). This test was done for each covariate within Model 1 and Model 2 i some covariates were combined into groups to lower the experimentwise error rate. Statistical results for Temperature and Site are not shown because of the significant Temperature-Site interaction term

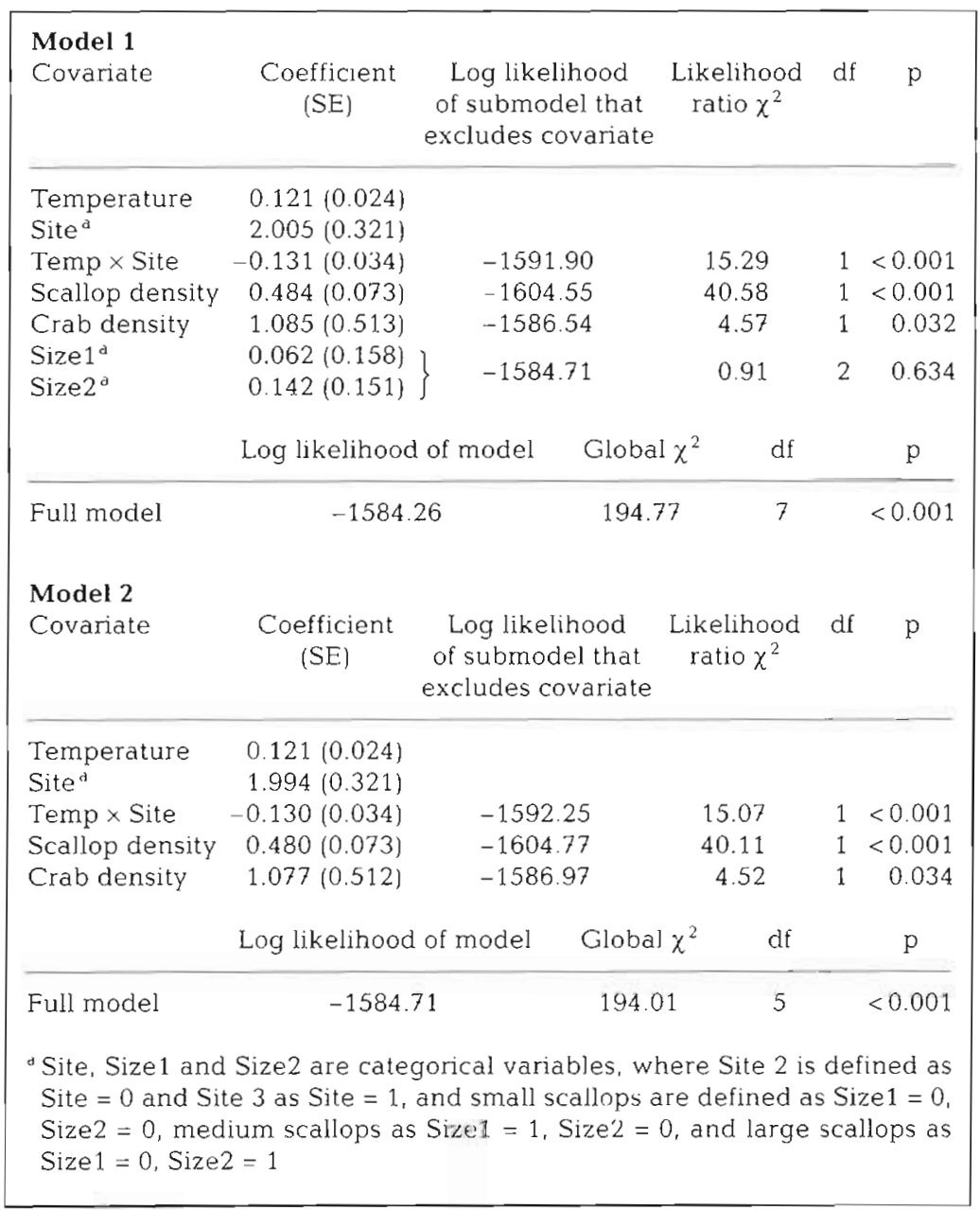

\section{DISCUSSION}

Through survival analysis of tethered scallops, we have examined the effects of biological and physical factors (i.e. scallop size, water temperature, site, scallop density and predator density) on the 2 major causes of mortality in juvenile sea scallops Placopecten magellanicus in natural habitats: predation by crabs Cancer irroratus and sea stars Asterias vulgaris and $A$. forbesi. Potential limitations of the tethering procedure are that it may bias the estimation of predation rate and may interact with other factors under study (Peterson \& Black 1994). Such interactions are most likely to occur with different habitats or sites, where different combinations of predators are present. Previous laboratory experiments showed that the effect of tethering on predation of juvenile scallops by crabs and sea stars was different (Barbeau \& Scheibling 1994b): tethering did not significantly increase predation rates by crabs, but greatly increased those by sea stars. This differential effect of tethering precluded assessment of the relative importance of crab and sea star predation in the field. To circumvent this problem, scallop survival times obtained from the tethering experiments were examined separately for crab and sea star predation through survival analysis. This procedure of censoring one cause of mortality while examining another is appropriate providing that the competing causes of mortality do not interact, which we showed to be the case. Other variables, such as prey size and density, and water temperature, also may interact with the tethering procedure, although inspection of our data and the consistency of our results with those of previous stud-

star density also did not significantly affect sea star predation (Table 4, Model 1). Temperature had a highly significant effect on sea star predation: the instantaneous mortality rate of scallops increased with temperature (Table 4, Model 2; Fig. 6). Scallop size also affected sea star predation: the instantaneous mortality rate of medium scallops did not differ significantly that of small scallops (Size1), but large scallops had a significantly lower instantaneous mortality rate than small scallops (Size2) (Table 4, Model 2; Fig. 6). ies suggested that such interactions were minimal.

Prey size is generally considered an important variable affecting prey vulnerability to predators (Osenberg \& Mittelbach 1989, Palmer 1990, Juanes 1992, Barbeau \& Scheibling 1994a). However, survival analysis indicated that scallop size had little effect on scallop mortality due to crab predation in our experiments (Table 3 ). The result contrasts with previous laboratory experiments (Barbeau \& Scheibling 1994a), which demonstrated that crabs consumed greater 

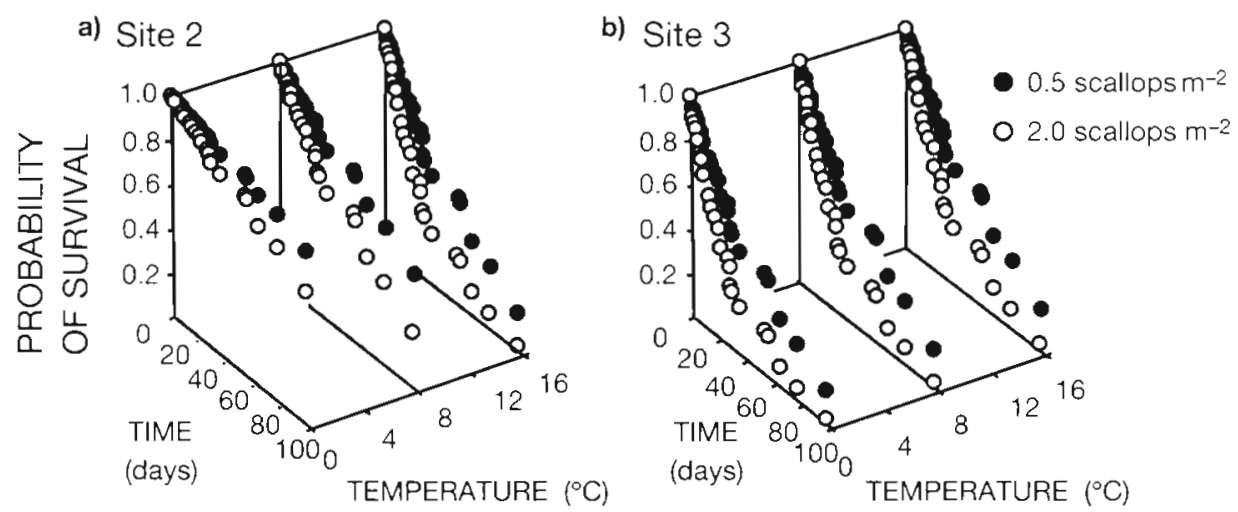

Fig. 5. Placopecten magellanicus. Simulated survival curves of tethered sea scallops for mortality attributed to predation by crabs Cancer irroratus at different water temperatures and scallop densities at (a) Site 2 and (b) Site 3 (calculated using Model 2 of the crab predation survival analysis; Table 3). The temperatures of 0,8 and $16^{\circ} \mathrm{C}$ were chosen to show scallop survivorship over the temperature range in the field. The scallop densities were chosen to reflect the approximate densities at the sites before seeding $\left(0.5\right.$ scallops $\left.\mathrm{m}^{-2}\right)$ and after seeding (2.0 scallops $\left.\mathrm{m}^{-2}\right)$. A crab density of 0.1 ind $\mathrm{m}^{-2}$ was used. The longest scallop survival time observed was $96 \mathrm{~d}$

numbers of large juvenile scallops $(20-25 \mathrm{~mm} \mathrm{SH})$ than small or medium scallops $(5-9 \mathrm{~mm}$ and $10-15 \mathrm{~mm}$ $\mathrm{SH})$, due to higher encounter rates of crabs with larger scallops than with small ones, and active selection for large scallops over medium-size ones. In our field experiments, crabs generally consumed more large scallops than smaller ones (Figs. 3 \& 4). Although this trend was apparent in the coefficients of the instantaneous mortality rate for size, it was not significant in the survival analysis (Table 3). The apparent discrepancy between field and laboratory results may be due to the large size range of crabs in the field (20 to $120 \mathrm{~mm}$ carapace width, CW; Barbeau et al. unpubl.) compared to that used in the laboratory experiments (45 to $110 \mathrm{~mm}$ CW; Barbeau \& Scheibling 1994a). Although we were unable to match predator and prey size in field experiments, smaller crabs probably consumed greater numbers of small scallops than large ones in the field, while larger crabs probably consumed mainly large scallops. This may explain the overall non-significant effect of scallop size in our analysis. Elner \& Jamieson (1979) observed that large crabs (90 to $130 \mathrm{~mm} \mathrm{CW}$ ) were able to open sea scallops up to $70 \mathrm{~mm} \mathrm{SH}$. Other scallop species appear to attain a size refuge from crab predation only around adult size (Lake et al. 1987, Minchin 1991, Pohle et al. 1991).

Analysis of scallop survival times indicated that scallop size was an important variable affecting scallop mortality due to sea star predation (Table 4, Fig, 6): the large size class experienced significantly lower mortality due to sea stars than small and medium size classes of scallops. This result is consistent with laboratory experiments (Barbeau \& Scheibling 1994a), which showed that smaller scallops had a less effective escape response to sea star attack than larger scallops and, therefore, had a higher probability of being captured. Scallops exhibit 2 types of escapes from sea stars: active escapes in which scallops swim or jump away from sea stars and retractions in which sea stars retract after contacting scallop tentacles, possibly due to a chemical deterrent (Moir 1977, Barbeau \& Scheibling 1994a). Although active escapes would be affected by tethering (Barbeau \& Scheibling 1994b), retractions would not. Retractions occurred more often with large scallops than with small ones (Barbeau \& Scheibling 1994a). Therefore, even when tethered, large scallops may have a lower probability of being captured than smaller scallops, resulting in lower mortality rates from sea stars in the field.

Water temperature is an important variable affecting predation rate and general physiological performance of marine invertebrates (Wallace 1973, Newell \& Branch 1980, Cossins \& Bowler 1987, Watts \& Lawrence 1990). The effect of temperature on scallop mortality due to crab predation in our field experiments differed between sites (Table 3, Fig. 5). At Site 2, the instantaneous mortality rate increased with temperature with a $Q_{10}$ of 3 , which is close to the relationship between temperature and crab predation rate observed in laboratory experiments $\left(Q_{10}=2\right.$; Barbeau \& Scheibling 1994c). At Site 3, the instantaneous mortality rate was independent of temperature $\left(Q_{10}=1\right)$. The site variable encompasses many aspects particular to a site, including topography, substratum, and predator densities. Site 3 is surrounded by rocky shores; this availability of shelter adjacent to the study site may explain the generally higher crab densities there than at Site 2 (Table 1) (see also Auster \& Malatesta 1991), and may have contributed to the site effect. The tem- 
Table 4. Placopecten magellanicus. Cox Proportional Hazards Analysis of mortality of scallops due to predation by sea stars Asterias spp. in the multifactor experiments at Sites 2 and 3 ir Lunenburg Bay. Model 1 quantifies the relationship between scallop mortality and all covariates. Model 2 includes only the temperature and scallop size covariates. The coefficient and its SE are shown for each covariate within each model. To test the significance of a covariate, the $\log$ likelihood of a submodel that excludes that particular covariate is statistically $\left(\chi^{2}\right)$ compared to the log likelihood of the full model (Model 1 or Model 2; listed on bottom line). The likelihood ratio test is defined as $-2(\log$ likelihood of submodel - log likelihood of full model). This test was done for each covariate within Model 1 and Model 2; some covariates were combined into groups to lower the experimentwise error rate

\begin{tabular}{|c|c|c|c|c|c|c|}
\hline $\begin{array}{l}\text { Model } 1 \\
\text { Covariate }\end{array}$ & $\begin{array}{l}\text { Coefficient } \\
\text { (SE) }\end{array}$ & \multicolumn{2}{|c|}{$\begin{array}{l}\text { Log likelihood of } \\
\text { submodel that } \\
\text { excludes covariate }\end{array}$} & $\begin{array}{l}\text { Likelihood } \\
\text { ratio } \chi^{2}\end{array}$ & $\mathrm{df}$ & $\mathrm{p}$ \\
\hline Temperature & $0.149(0.014)$ & \multicolumn{2}{|c|}{-2428.12} & 127.96 & 1 & $<0.001$ \\
\hline $\begin{array}{l}\text { Size } 1^{a} \\
\text { Size2 }^{a}\end{array}$ & $\begin{array}{l}-0.166(0.112) \\
-1.034(0.135)\end{array}$ & \multicolumn{2}{|c|}{-2399.94} & 71.59 & 2 & \\
\hline $\begin{array}{l}\text { Sitc }^{\circ} \\
\text { Scallop density } \\
\text { Sea star density }\end{array}$ & $\begin{array}{r}0.077(0.111) \\
-0.003(0.061) \\
-0.008(0.161)\end{array}$ & \} & & 0.62 & \multirow[t]{2}{*}{3} & 0.891 \\
\hline & \multicolumn{2}{|c|}{ Log likelihood of model } & \multicolumn{2}{|c|}{ Global $\chi^{2}$} & & $\mathrm{p}$ \\
\hline Full model & -2364.1 & & 191.54 & 6 & & $<0.001$ \\
\hline $\begin{array}{l}\text { Model } 2 \\
\text { Covariate }\end{array}$ & $\begin{array}{l}\text { Coefficient } \\
\qquad \text { (SE) }\end{array}$ & \multicolumn{2}{|c|}{$\begin{array}{l}\text { Log likelihood of } \\
\text { submodel that } \\
\text { excludes covariate }\end{array}$} & $\begin{array}{l}\text { Likelihood } \\
\text { ratio } \chi^{2}\end{array}$ & $\mathrm{df}$ & $\mathrm{p}$ \\
\hline \multirow[t]{2}{*}{$\begin{array}{l}\text { Temper } \\
\text { Size1 }^{d} \\
\text { Size2 }^{d}\end{array}$} & $\begin{array}{r}0.149(0.013) \\
-0.165(0.112) \\
-1.034(0.135)\end{array}$ & \multicolumn{2}{|c|}{$\begin{array}{l}-2434.54 \\
-2365.54 \\
-2395.83\end{array}$} & $\begin{array}{r}140.18 \\
2.17 \\
62.75\end{array}$ & $\begin{array}{l}1 \\
1 \\
1\end{array}$ & $\begin{array}{r}<0.001 \\
0.141 \\
<0.001\end{array}$ \\
\hline & \multicolumn{2}{|c|}{ Log likelihood of model } & Global $\chi$ & $\mathrm{df}$ & & $\mathrm{p}$ \\
\hline $\begin{array}{l}\text { 'Site, Size } 1 \text { and } \\
\text { Site }=0 \text { and Sit } \\
\text { Size } 2=0, \text { med } \\
\text { Size } 1=0, \text { Size2 }\end{array}$ & $\begin{array}{l}-2364.4 \\
\text { Size2 are categ } \\
\text { e } 3 \text { as Site }=1 \text {, a } \\
\text { ium scallops as }\end{array}$ & $\begin{array}{l}\text { gorical var } \\
\text { and small } \\
\text { Size } 1=1\end{array}$ & $\begin{array}{l}189.85 \\
\text { les, wher } \\
\text { llops are } \\
\text { ze } 2=0\end{array}$ & $\begin{array}{l}3 \\
\text { ere Site } 2 \\
\text { e defined } \\
\text {, and larg }\end{array}$ & & $\begin{array}{l}\text { ze } 1=0 \\
\text { llops as }\end{array}$ \\
\hline
\end{tabular}

ture. Lower movement velocities of sea stars in the field $\left(1 \mathrm{~cm} \mathrm{~min}^{-1}\right.$ at $\left.12^{\circ} \mathrm{C}\right)$ compared to those observed in laboratory experiments $\left(3\right.$ and $7 \mathrm{~cm} \mathrm{~min}^{-1}$ at 8 and $15^{\circ} \mathrm{C}$, respectively; Barbeau \& Scheibling 1994c) may be due to the availability of alternative prey and low predator searching times. This may explain the smaller effect of temperature on rates of sea star predation in the field experiments than in the previous laboratory experiments. Also, the temperature variable in the multifactor experiments was confounded by other seasonal variables (e.g. physiological state of the animals), which may have contributed to the differences in the apparent temperature effects on sea star and crab predation between the field and laboratory experiments.

Short-term increases in prey mortality rates with increases in prey density may result from a functional response and/or a numerical aggregative response of the predator (Holling 1966, Hughes 1980, Taylor 1984). Analysis of scallop survival times indicated that scallop density was an important variable affecting scallop mortality due to crab predation in the field (Table 3, Fig. 5). In the single-factor experiment at Site 1, crabs displayed a functional response to increasing scallop densities since crabspecific mortality rates of scallops increased significantly with scallop density, but crab density did not (Fig. 2). We attribute this functional response to high movement velocity and short prey handling time of crabs, and to the relative importance of encounter rate in determining their predation rate

perature dependence of crab predation may be reduced at high crab densities or during periods when crabs increase consumption rate in response to increases in prey density.

Water temperature had a strong effect on sea star predation on scallops in the field, which was consistent between sites (Table 4, Fig. 6). The instantaneous mortality rate increased with temperature with a $Q_{10}$ of 4. Laboratory experiments have also shown a marked effect of temperature on sea star predation rates $\left(Q_{10}=7\right.$; Barbeau \& Scheibling 1994c), due to increased sea star foraging activity (searching time, movement velocity, encounter rate) and decreased scallop escape effectiveness with increasing tempera- on scallops (Barbeau \& Scheibling 1994a, c). Functional responses have also been observed in other crab-bivalve interactions (Boulding \& Hay 1984, Lipcius \& Hines 1986, Eggleston 1990, Sponaugle \& Lawton 1990, Eggleston et al. 1992). The survival analysis also indicated that crab density had an effect on mortality rates of scallops at Sites 2 and 3 (Table 3). This result may be due to the generally higher density of crabs at Site 3 than at Site 2, rather than to an actual increase in crab density after seeding the sites (i.e. aggregative response). In a total of 5 seeding trials at Sites 1,2 and 3, crab density did not increase or increased slightly after seeding (Hatcher et al. 1993, in press). 


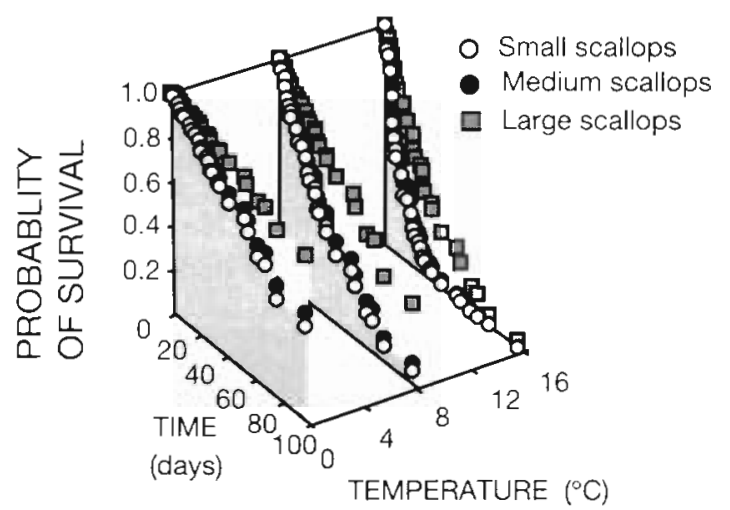

Fig. 6. Placopecten magellanicus. Simulated survival curves of different size classes of tethered sea scallops for mortality attributed to predation by sea stars Asterias spp. at different water temperatures (calculated using Model 2 of the sea star predation survival analysis; Table 4). The temperatures of 0 , 8 and $16^{\circ} \mathrm{C}$ were chosen to show scallop survivorship over the temperature range in the field. The longest scallop survival time observed was $96 \mathrm{~d}$

Survival analysis indicated that scallop density was not an important factor affecting scallop mortality from sea star predation in the field (Table 4). This observation is supported by the results of the single-factor experiment at Site 1, which showed that the sea-starspecific mortality rate of tethered scallops was not affected by scallop density (Fig. 2). Sea star consumption rate may be limited by high prey handling times and slow movement velocities (Jangoux 1982, Barbeau \& Scheibling $1994 \mathrm{a}, \mathrm{c})$. This may explain the lack of a functional response by sea stars to increased prey densities. As well, sea stars did not have an aggregative response to increased scallop densities in the singlefactor experiment at Site 1. In the analysis of survival times of tethered scallops at Sites 2 and 3, sea star density was not significant in affecting scallop mortality (Table 4), which may reflect the fact that sea star density did not vary much within and between sites over time (Table 1). In the scallop seeding experiment at Site 1, sea star density did not increase significantly after the release of 10000 juvenile scallops at a density of about $250 \mathrm{~m}^{-2}$ (Hatcher et al. in press). In contrast, Volkov et al. (1983) observed sea stars Distolasterias nipon to aggregate and follow patches of released scallops Patinopecten yessoensis. Density-dependent effects on predation appear to be species-specific.

The results of our field tethering experiments have important implications for the bottom culture of sea scallops. The probability of capture by sea stars is low, since scallops have an effective escape response against sea stars. To minimize predation by sea stars, large ( $\geq 25 \mathrm{~mm} \mathrm{SH}$ ) juvenile scallops should be used in bottom culture, although they remain vulnerable to crab predation. Predation by crabs may be reduced by lowering encounter rates, either by seeding scallops at low densities or by lowering crab densities through predator removal procedures. Moreover, seeding scallops at low temperature lowers predation rates, particularly by sea stars, and should increase the success of bottom culture. Finally, survival analysis of tethered prey provides an informative measure of predation intensity, which can be used to assess potential bottom culture sites and predator control tactics.

Acknowledgements. We thank T Balch, D. Barbeau, A. Carson, S. Kleinman, S. Lothian, P. McKenna, K. Richard, and A. Windust for diving and/or tethering assistance. W. Blanchard of the Statistical Consulting Service of Dalhousie University provided advice on survival analysis. C. H. Peterson offered valuable comments on the manuscript. M.A.B. was supported by a Natural Sciences and Engineering Research Council of Canada (NSERC) Postgraduate Scholarship, a 'Fonds pour la Formation de Chercheurs et l'Aide à la Recherche' (FCAR, Quebec) Postgraduate Scholarship and an lzaak Walton Killam Memonal Scholarship. The research was funded by an NSERC Operating Grant and an NSERC Networks of Centres of Excellence Grant (Ocean Production Enhancement Network) to R.E.S.

\section{LITERATURE CITED}

Auster, P. J., Malatesta, R. J. (1991). Effects of scale on predation patterns. In: Shumway, S. E., Sandifer, P. A. (eds) An international compendium of scallop biology and culture World Aquaculture Workshops No. 1. World Aquaculture Society, Baton Rouge, p. 198-203

Barbeau, M. A. (1994). Predator-prey interactions between juvenile sea scallops (Placopecten magellanicus) and predatory sea stars (Asterias spp.) and crabs (Cancer irroratus). Ph.D thesis, Dalhousie University, Halifax

Barbeau, M. A., Scheibling, R. E. (1994a). Behavioral mechanisms of prey size selection by sea stars (Asterias vulgaris Verrill) and crabs (Cancer irroratus Say) preying on juvenile sea scallops (Placopecten magellanicus [Gmelin]). J. exp. mar. Biol. Ecol. 180: 103-136

Barbeau, M. A., Scheibling, R. E. (1994b). Procedural effects of prey tethering experiments: predation of juvenile scallops by crabs and sea stars. Mar. Ecol. Prog. Ser. 111: 305-310

Barbeau, M. A., Scheibling, R. E. (1994c). Temperature effects on predation of juvenile sea scallops (Placopecten magellanicus [Gmelin]) by sea stars (Asterias vulgaris Verrill) and crabs (Cancer irroratus Say). J. exp. mar. Biol. Ecol. 182: $27-47$

Boghen, A. D. (ed.) (1989). Cold-water aquaculture in Atlantic Canada. The Canadian Institute for Research on Regional Development, Moncton, NB

Boulding, E. G., Hay, T. K. (1984). Crab response to prey density can result in density-dependent mortality of clams. Can. J. Fish. Aquat. Sci. 41:521-525

Cossins, A. R., Bowler, K. (1987). Temperature biology of animals. Chapman \& Hall, New York

Crowder, M. J., Hand, D. J. (1990). Analysis of repeated measures. Chapman \& Hall, London

Dixon, W. J. (1990). BMDP statistical software manual. University of California, Berkeley 
Eggleston, D. B. (1990). Behavioural mechanisms underlying variable functional responses of blue crabs, Callinectes sapidus feeding on juvenile oysters, Crassostrea virginica. J. Anim. Ecol. 59:615-630

Eggleston, D. B., Lipcius, R. N., Hines, A. H. (1992). Densitydependent predation by blue crabs upon infaunal clam species with contrasting distribution and abundance patterns. Mar. Ecol. Prog. Ser. 85: 55-68

Elner, R. W., Jamieson, G. S. (1979). Predation of sea scallops, Placopecten magellanicus, by the rock crab, Cancer irroratus, and the American lobster, Homarus americanus. J. Fish. Res. Bd Can. 36: 537-543

Emerson, C. M. Grant, J. (in press). Empirical predictions of scallop production: dependence on sampling frequency of oceanographic processes. In: Proceedings of the 9th International Pectinid Workshop. Can. Tech. Rep. Fish. Aquat. Sci.

Flagg, P. J., Malouf, R. E. (1983). Experimental plantings of juveniles of the hard clam Mercenaria mercenaria (Linné) in the waters of Long Island, New York. J. Shellfish Res. 3: $19-27$

Hatcher, B. G., Scheibling, R. E., Barbeau, M. A., Taylor, L. H., Hennigar, A. W. (1993). 'Why not just throw 'em on the bottom?' Seabed seeding of scallops in Nova Scotia. Bull. Aquacult. Ass. Can. 93-4: 132-134

Hatcher, B. G., Scheibling, R. E., Barbeau, M. A., Taylor, L. H., Hennigar, A. W., Windust, A. (in press). Mortality and dispersion of juvenile sea scallops (Placopecten magellanicus) seeded in a tidal channel. Can. J Fish. Aquat. Sci.

Holling, C. S. (1966). The functional response of invertebrate predators to prey density. Mem. ent. Soc. Can. 48:1-86

Hughes, R. N. (1980). Predation and community structure. In: Price, J. H., Irvine, D. E. G., Farnham, W. F. (eds.) The shore environment, Vol. 2: Ecosystems. Academic Press, New York, p. 699-728

Jangoux, M. (1982). Food and feeding mechanisms: Asteroidea. In: Jangoux, M., Lawrence, J. M. (eds.) Echinoderm nutrition. A. A. Balkema, Rotterdam, p. 11.7-159

Jensen, K. T., Jensen, J. N. (1985). The importance of some epibenthic predators on the density of juvenile benthic macrofauna in the Danish Wadden Sea. J. exp. mar. Biol. Ecol. 89: 157-174

Juanes, F. (1992). Why do decapod crustaceans prefer smallsized molluscan prey? Mar. Ecol. Prog. Ser. 87: 239-249

Jubb, C. A., Hughes, R. N., ap Rheinallt, T (1983). Behavioural mechanisms of size-selection by crabs, Carcinus maenas (L.) feeding on mussels, Mytilus edulis L. J. exp. mar. Biol. Ecol. 66: 81-87

Kalbfleisch, J. D. Prentice, R. L. (1980). The statistical analysis of failure time data. John Wiley \& Sons, New York

Lake, N. C. H., Jones, M. B., Paul, J. D. (1987). Crab predation on scallop (Pecten maximus) and its implication for scallop cultivation. J. mar. biol. Ass. U.K. 67: 55-64

Lawless, J. F. (1982). Statistical models and methods for lifetime data. John Wiley \& Sons, New York

Lipcius, R. N. Hines, A. H. (1986). Variable functional responses of a marine predator in dissimilar homogeneous microhabitats. Ecology 67: 1361-1371

Minchin, D. (1991). Decapod predation and the sowing of the scallop, Pecten maximus (Lunnaeus, 1758). In: Shumway, S. E., Sandifer, P. A. (eds.) An international compendium of scallop biology and culture. World Aquaculture Workshops No. 1 World Aquaculture Society, Baton Rouge, p. 191-197

This article was presented by R. N. Hughes (Senior Editorial Advisor), Bangor, UK
Moir, A. J. G. (1977). Ultrastructural studies on the ciliated receptors of the long tentacles of the giant scallop, Placopecten magellanicus (Gmelin). Cell Tissue Res. 184 $367-380$

Muenchow, G. (1986). Ecological use of failure time analysis Ecology 67: 246-250

Naidu, K. S., Cahill, F. M. (1986). Culturing giant scallops in Newfoundland waters. Can. MS Rep. Fish. Aquat. Sci. No. 1876

Newell, R. C., Branch, G. M. (1980). The influence of temperature on the maintenance of metabolic energy balance in marine invertebrates. Adv. mar. Biol. 17: 329-396

Osenberg, C. W., Mittelbach, G. G. (1989). Effects of body size on the predator-prey interaction between pumpkinseed sunfish and gastropods. Ecol. Monogr. 59: 405-432

Palmer, A. R. (1990). Predator size, prey size, and the scaling of vulnerability: hatchling gastropods vs barnacles. Ecology 71.759-775

Peterson, C. H. (1982). Clam predation by whelks (Busycon spp.): experimental tests of the importance of prey size, prey density and seagrass cover. Mar. Biol. 66: 159-170

Peterson, C. H. (1990). On the role of ecological experimentation in resource management: managing fisheries through mechanistic understanding of predator feeding behaviour. In: Hughes, R. N. (ed.) Behavioural mechanisms of food selection, Springer-Verlag, New York, p. 821-846

Peterson, C. H., Black, R. (1994). An experimentalist's challenge: when artifacts of intervention interact with treatments. Mar. Ecol. Prog. Ser. 11 1: 289-297

Picard, P. (1992). Essais d'ensemencement de pétoncle géant sur les fond à potentiel pectinicole aux lles-de-lat Madeleine. Rapport annuel. Roche ltée Groupe-Conseil, Sainte-Foy, PQ

Pohle, D. G., Bricelj, V. M., Garcia-Esquivel, Z. (1991). The eelgrass canopy: an above-bottom refuge from benthic predators for juvenile bay scallops Argopecten irradians Mar. Ecol. Prog. Ser. 74: 47-59

Sanchez-Salazar, M. E., Griffiths, C. L., Seed, R. (1987). The effect of size and temperature of the predation of cockles Cerastoderma edule (L.) by the shore crab Carcinus maenas (L.). J exp. mar. Biol. Ecol. 111: 181-193

Sponaugle, S., Lawton, P. (1990). Portunid crab predation on juvenile hard clams: effects of substrate type and prey density. Mar. Ecol. Prog. Ser. 67: 43-53

Taylor, R. J. (1984). Predation. Chapman \& Hall, New York

Tremblay, M. J. (ed.) (1988). A summary of the proceedings of the Halifax sea scallop workshop. August 13-14, 1987. Can. Tech. Rep. Fish. Aquat. Sci. 1605

Volkov, Y P., Dadaev, A. A., Levin, V S., Murakhveri, A. M. (1983). Changes in the distribution of Yezo scallop and starfishes after mass planting of scallops at the bottom of Vityaz' Bay (Sea of Japan). Sov. J. mar. Biol. 8: 216-223

Wallace, J. C. (1973). Feeding, starvation and metabolic rate In the shore crab Carcinus maenas. Mar. Biol. 20:277-281

Watts, S. A., Lawrence, J. M. (1990). The effect of temperature and salinity interactions on righting, feeding and growth in the sea star Luidia clathrata (Say). Mar. Behav. Physiol. 17: $159-165$

Wildish, D. J., Wilson, A. J., Young-Lai, W., DeCoste, A. M. Aiken, D. E., Martin, J. D. (1988). Biological and economic feasibility of four grow-out methods for the culture of giant scallops in the Bay of Fundy. Can. Tech. Rep. Fish. Aquat. Sci. 1658

Winer, B. J. (1971). Statistical principles in experimental design, 2nd edn. McGraw-Hill, New York 